\title{
THE PHYLOGENY OF THE ELATERIDAE BASED ON LARVAL CHARACTERS.
}

By J. A. Hyslor, Bureau of Entomology, Washington, D. C.

The object of the present paper is to accentuate the value of studies of the larval characters in attempting a natural classification of the Coleoptera, and to present a new arrangement of the Elateridæ based upon such studies. The paper is preliminary and based largely upon the external characters of the larvæ. Seventy-nine names have been recognized at one time or another for genera occurring in our fauna, but, after considering synonomy and misidentification, this number can be reduced to between forty and fifty. Practically all of the common holoartic genera are represented. Specimens of the larvæ of thirtyeight genera have been studied. The fourteen or more genera whose larvæ are still unknown are as follows: The genus $\mathrm{Mel}$ anactes, containing seven species, two of which are quite common; the genus Esthesopus, containing six species; Paranomus, four; Leptoschema, three; Oxygonus, Eniconyx and Meristhus, two each; and Nothodes, Bladus, Elatrinus, Blauta, Oedostethus, Aptopus and Coptostethus, one each. In the absence of reared material, the characters of the genera Ischnodes, Ectinus, Adrastus, Hypnoidus and Lepturoides were drawn from literature. With these exceptions, the larvæ of species representing all the genera herein treated were examined by the writer and the generic characters drawn from the last larval exuvium of individuals of which the imago was reared and carefully determined. In many of the genera several species were examined.

I wish to express my sincere gratitude to Mr. E. A. Schwarz, of the U. S. National Museum, without whose kindly assistance the work would have been impossible; to the late Professor F. M. Webster, who permitted the use of the material in the Division collection; to Mr. H. S. Barber, who facilitated the use of the Museum material; to Mr. C. W. Johnson, of the Boston Society of Natural History, who very kindly allowed me to use the material in the Thaddeus Harris collection; and to Dr. A. D. Hopkins and Mr. F. C. Craighead, of the Division of 
Forest Insect Investigation, for the use of their very valuable material. I am deeply indebted to Dr. Adam Böving, of the same Division, who gave invaluable assistance in homologizing the sclerites in several genera, and who helped in countless other ways, both with material from Europe and his broad knowledge of Coleopterous larvæ.

The principal works consulted were: Schiodte ${ }^{1}$ (1861-69), Perris² (1852-1863), Candeze ${ }^{3}$ (1861), Henriksen ${ }^{4}$ (1911), and Gahan $^{5}$ (1911), and also the principal works on classification of the adult beetles.

Before proceeding with the classification of the Elateridæ as we now understand this family, I will briefly discuss the older group Sternoxes of Latereille ${ }^{6}$ (1802). This is still recognized by such renowned authorities as Kolbe (1901) and Gahan (1911) to be a natural super-group. Lacordaire ${ }^{7}$ (1857) subdivided this group into six families, the Elaterides, Cerophytides, Cebrionides, Eucnemides, Throscides and Buprestides, which with but few changes, have stood to the present time. Drs. Leconte and Horn (1883) in their classification reduced the Cerophytidæ, Cebrionidæ and Eucnemidæ to subfamilies, erecting an additional subfamily, the Perothopinæ, to include the genus Perothops formerly included in the Eucnemidæ, but rejected from that family by de Bonvoluoir in his Monograph. This last author retained the Cerophyidæ in the Eucnemidæ, but Leconte and Horn believed that it should represent a subfamily connecting the Eucnemidæ with the Dascyllidæ. Kolbe (1901) re-established these families, adding the Dicronychidæ which is considered by Gahan (1911) to be very closely related to the Plastoceridæ of the more recent authors and which I reduce to subfamily rank. The classification herein proposed agrees with that of Kolbe ${ }^{8}$ (1901) in elevating the Leconte and Horn subfamilies to family rank, but would indicate the relationship of these families by establishing a superfamily Elateroidea.

${ }^{1}$ Metamorphosi Eleutheratorum Observationees, 1861-69. Classification of the Buprestidae and Elateridae (Natur. Hist. Tidssk., Ser. 3, Vol. III, Copenhagen, 1865.

${ }_{2}^{2}$ Histoire des Insects du Pin Maritime (Ann. Soc. Ent. France), 1852-63.

${ }^{3}$ Histoire des Metamorphoses de quelques Coleopteres Exotiques, Liege, 1861.

${ }^{4}$ Oversight over de danske Elateridae-larvae (Entomologie Meddelelser, part 2, Vol. IV, 1911

${ }^{5}$ Classification of the Coleoptera (The Entomologist, Vol. XLIV), 1911.

${ }^{6}$ Hist. Nat. etc. Tome III, p. 99, 1802.

${ }^{7}$ Hist. Nat. des Ins. Col. IV, p. 1-246, 1857.

${ }^{8}$ Arch. fur Naturg. 1901, p. 39. 
I do not consider the Buprestidæ as at all related to this superfamily, and have not yet studied the Throscidæ. Mr. F. C. Craighead has very recently loaned me a larval exuvium of Drapetes geminatus Say. This species, heretofore referred to the Throscidæ, is certainly very closely allied to the Elateridæ of the subfamily Oestodinæ in its larval characters. Through the kindness of Dr. Böving I have received specimens of Throscus dermestoides from Mr. C. E. Rosenberg, of Copenhagen, which are most assuredly not closely allied to the Elateridæ, and conclude that on the present evidence it will be necessary to remove the genus Drapetes from the Throscidæ.

The hitherto supposed relationship of the Elateridæ and Buprestidæ, using the Eucnemidæ as the connecting link, is undoubtedly erroneous, the larval resemblance being purely superficial. The characters formerly used to differentiate the Eucnemidæ from the Elateridæ have failed to hold even with the few specimens I have examined. They are not as has generally been conceded, universally apodus as is clearly to be seen in an undoubted Eucnemid larva occurring in rotten logs in the Eastern States, in which distinct, though rudimentary, legs are evident. The mouthparts are adapted to wood boring, so their unique structure cannot be given overmuch taxonomic weight, and the tenth abdominal segment is situated ventrocephalad to the ninth as in the Elateridæ. The careful anatomical studies made by Schiodte $^{9}$ (1847 and 1865) of the adults separate the Elateridæ and Buprestidæ very widely. The old group Sternoxes, as we now understand it, consists of three groups: the superfamily Elateroidea; the family Throscidæ, part of which may eventually be placed in this superfamily; and the family Buprestidæ. The superfamily Elateroidea embraces the families Cerophytidæ, Cebrionidæ, Plastoceridæ, Elateridæ and Eucnemidæ. The Cerophytidæ and Plastoceridæ are unknown as larvæ. Their very doubtful position cannot fail to be somewhat more positively determined by their larvæ when these are described. The plate (Fig. 1) indicates in outline the various concepts of this complex.

${ }^{9}$ (Naturhist. Tidssk. ser. 3, Vol. III, 1865) and Konge. Danske Viden. Selsk. Forh. 1847). 


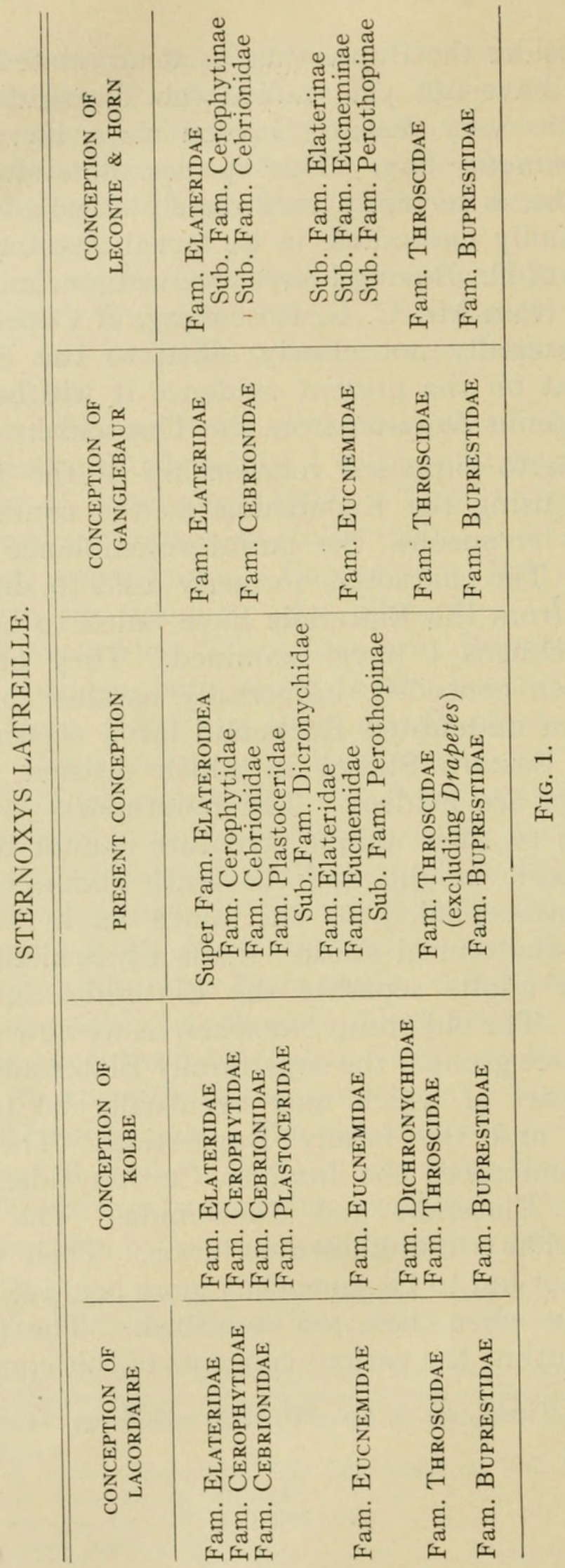


The larvæ of the Elateridæ, as here restricted, are distinguished by the following characters: (1) The lower mouthparts inserted, that is to say, the hypostoma strongly curved caudad and the maxillary stipes and cardo inserted far behind the mandibular articulation. (2) Labrum not defined; it may be aborted or it may be fused with the post-labrum and front into the nasal lobe. (3) Spiracles of the biforian type. Three-jointed antennæ. (5) Well-developed thoracic legs. (6) Unguiform tarsi. (7) Tenth segment ventrocephalad to the ninth. (8) No cerci. (9) Mandibles not perforate as in some Lampyridæ, etc.

Schiodte, using larval characters, divided the Elateridæ, in which he also included our present families Cebrionidæ and Eucnemidæ, into two main groups, basing his conclusions on the presence or absence of anal armature. Group 1 contained the Eucnemidæ and group 2 the Elateridæ and Cebrionidæ. He subdivided his Elateridæ, in the narrow sense, into main divisions $\mathrm{A}$ and $\mathrm{B}$, the former embracing Cardiophorus, Chalcolepidius, Alaus, Agrypnus and Lacon; the latter the remainder of the family as known to him, including the Cebrionidæ. With the exception of the genus Cardiophorus, I include all the genera of his division A in my tribe Pyrophorini. He separated his second division into categories on the shape of the ninth abdominal segment. The first of these categories, those species without posteriorly directed paired prongs, includes the genera which I refer to my subfamily Elaterinæ, and the second, in which occur manifestly paired prongs on the ninth abdominal segment, includes the genera referred to the tribe Lepturoidini of my subfamily Pyrophorinæ.

Henriksen follows Schiodte in using the presence or the absence of anal armature to primarily subdivide the Elateridæ into the tribes Agrypnini and Elaterini. This division is not at all natural as it widely separates such manifestly closely related forms as Limonius and Ludius Esch. (which we have been erroneously calling Corymbites) and brings together such distinct tribes as the Steatoderini and Athouini. A much more natural division is based upon the depressed body, visible and membraneous pleural areas, and emarginate ninth abdominal segment; in contrast with the cylindrical, highly chitinized body, concealed pleuræ, and entire ninth abdominal segment. 
This conclusion is strengthened by the systematic arrangement of these insects as conceived by the more eminent workers of the group and based almost exclusively on adult characters.

The first, third and fourth tribes of Candeze (1857)* Agrypnides, Hemirhipides, Chalcolepidides, fall naturally under my Pyrophorini. His second tribe, Melanactides, is still unknown in the larval stage and we can expect much light to be thrown upon its phyletic position when the larvæ are described. Candeze states that the tribe serves as a connecting link between the Agrypnides and the Hemirhipides. The type genus of the tribe was established by LeConte (1853) for several North American species placed by Eschscholtz in his Ludius and by Germar in Pristilophus, both genera now usually considered as Corymbites Latr. Whether the larvæ of these insects will show a relationship between my tribes Pyrophorini and Lepturoidini or will reduce the tribe Melanactides to synonomy under one of the other tribes, remains to be discovered. $\mathrm{He}$ includes in his seventh tribe, Elaterides vrais, the Pyrophorina and Monocrepidina, which I consider should be placed at the end of the tribe Pyrophorini as the transient forms between the two tribes of this subfamily, and not at all closely related to the other subtribes which he places in this tribe. Excluding these two groups of genera, the tribe Elaterides vrais agrees with the primary division of Schiodte and Henriksen, and may have suggested the high ordinal value that these more recent writers gave to the presence or absence of anal armature. Candeze's division of his two great tribes into subtribes, however, is remarkably illuminating from our view point, in many respects bearing out the conclusions here set forth. His subtribe Ludites includes the tribes Steatoderini and Agriotini of my subfamily Elaterinæ. His Campylites, which he places at the end of his classification and considers very distinct from the other tribes, I place at the end of the tribe Lepturoidini, though undoubtedly many of the genera in the Campylites -will be found to belong in other tribes than that of the type genus. In his later work $\dagger$ (1891) Candeze disregarded the two tribes of his Monograph and raised all his subtribes to tribal rank.

* Monogr. des Elat. Tome 1, (1857).

$\dagger$ Cat. Method. des Elat. 1891. 
Leconte and Horn (1883) agree with Candeze (1857) in tribal arrangement, except that they reduce Campylites to a subtribe under the Athoui, which I believe to be much nearer to the true position of the genus Campylus than that given by Candeze. Their division into subtribes, based primarily upon the shape of the posterior coxal plates, has led them into some very grave errors and seems to indicate that the form of the "plaque nasale" used by Candeze as of primary importance has much higher ordinal value. Their subtribe Corymbitini includes such widely separated forms as Pyrophorus, which belongs to my subfamily Pyrophorinæ, Athous, belonging to the same subfamily, but tribe Lepturoidini; A grypmus, belonging to the same subfamily, tribe Pyrophorini; Sericosomus, belonging to the subfamily Elaterinæ and tribe Steatoderini; and Melanotus to the tribe Melanotini. Their subtribe Elaterini includes Monocrepidius, of my subfamily Pyrophorinæ, tribe Pyrophorini; Cryptohypnus, of the same subfamily but in tribe Lepturoidini; Tricophorus, of the subfamily Elaterinæ, tribe Steatoderini; and Elater and Megapenthes, of the tribe Elaterini.

O. Schwarz (1906) in Genera Insectorum follows Candeze (1891) with but few exceptions. He raises Candeze's Plastocerini to family rank; adds the tribe Octocryptini to receive the single genus Octocryptus Candeze; Physodactylini to include several genera from South America and Africa; and changes six tribal names in accordance with the rules of nomenclature.

\section{PYROPHORINÆ.}

My first subfamily, the Pyrophorinæ, is characterized by having the larvæ (Fig. 2) dorso-ventrally depressed, with the ninth abdominal segment emarginate posteriorly, and the pleural areas membranous and visible; while in the adult the front is usually flat or concave, the "plaque nasale" when present is wide and the antennal fossæ small.

This subfamily is divided into four tribes, the first of which, the Pyrophorini, is characterized in the larvæ (Fig. 2) by having the submentum triangular, bases of stipes-maxillæ contiguous, and mandibles without teeth on the inner surface; and in the adults, by the absence of the cubital cross vein in the wings. This vein is present in all the other groups with but one or two exceptions, which will be mentioned later. 


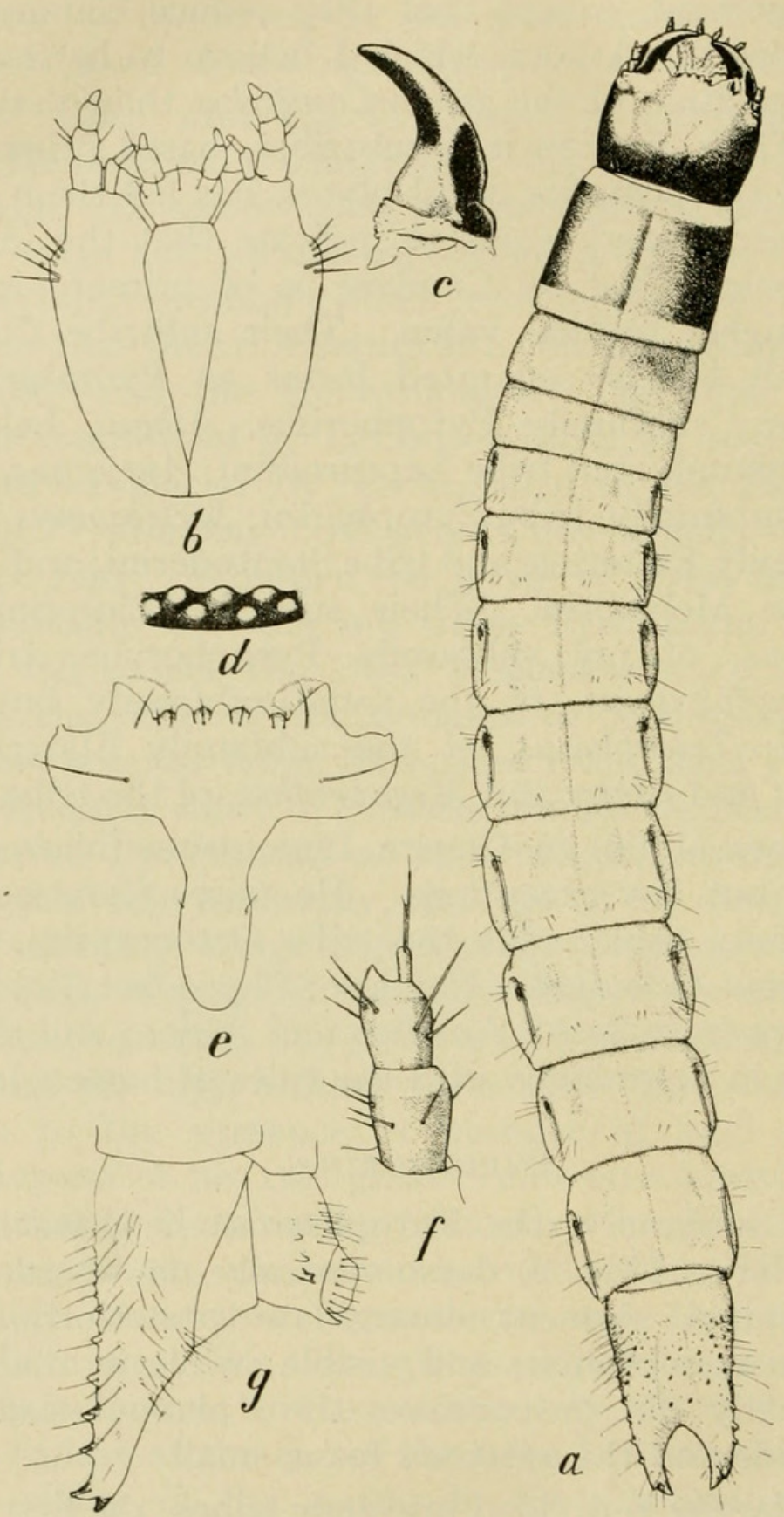

Fig. 2. Pyrophorus luminosus Illig. a, dorsal aspect of larva; b, ventral aspect of labium and maxillae; c, ventral aspect of left mandible; d, anterior aspect of nasale; e, nasale and front; f, antenna; g, lateral aspect of 9 th and 10 th abdominal segments. 
The second tribe of the Pyrophorinæ, the Pityobini (Fig. 3 ), is characterized in the larval stage by having the submentum triangular and the mandibles with three teeth on the inner surface. The adults have flabellate antennæ in the males; a distinct transverse carina on the front above the "plaque nasale;" joints two to four of the tarsi with short
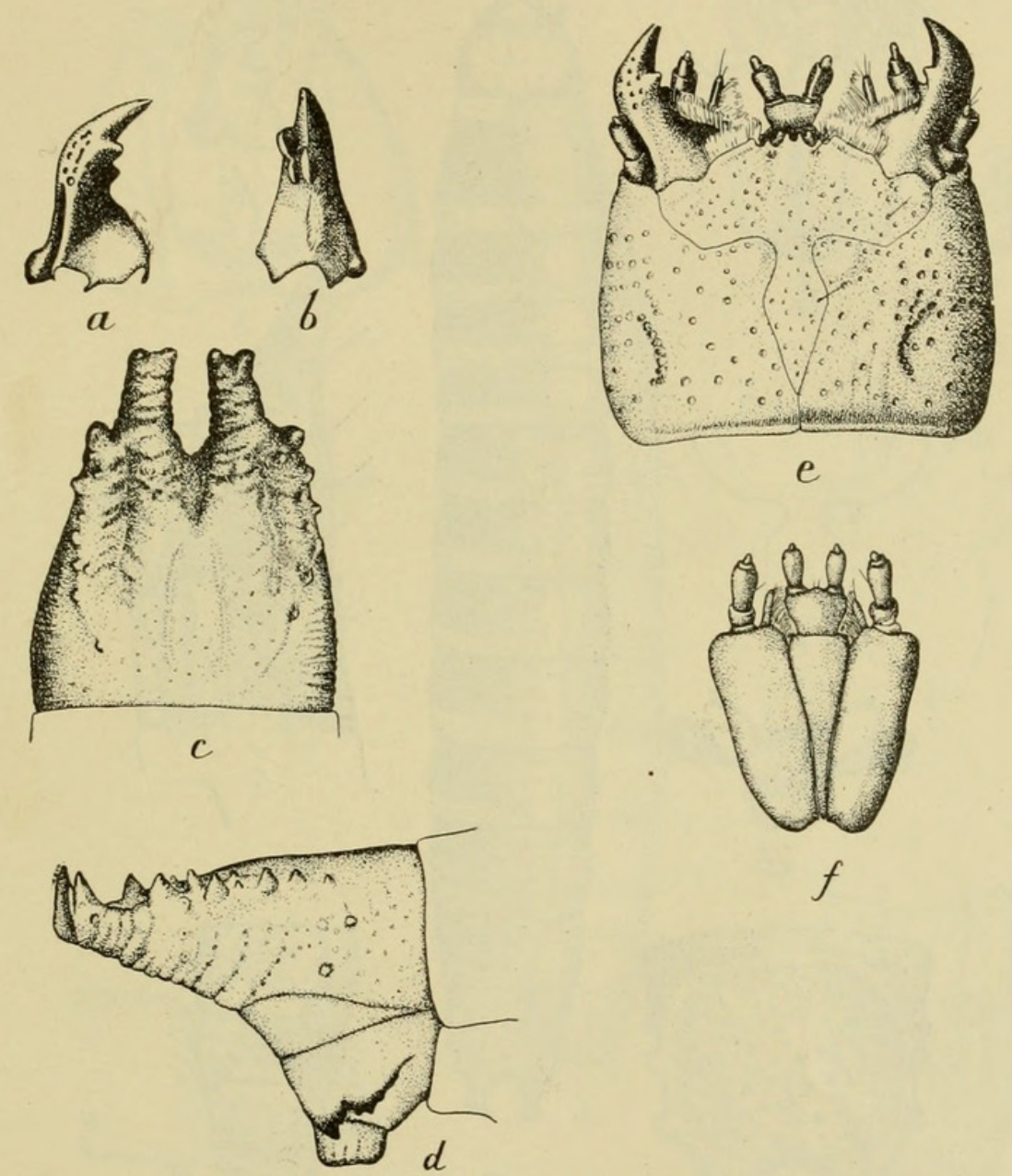

Fig. 3. Pityobius anguinus Lec. a, dorsal aspect of left mandible; b, inner aspect of same; c, dorsal aspect of 9 th abdominal segment; d, lateral aspect of 9 th and 10th abdominal segments, (10th reconstructed); e, dorsal aspect of head; f, labium and maxillae.

lobes and the first tarsal joint longer than the two following joints united. This tribe is of remarkable interest as it is intermediate between the two main subdivisions erected by Schiodte and Henriksen, having the retinaculum of their second tribe and the triangular submentum of their first tribe. This bears out my conclusion that the shape of the ninth abdominal 
segment, and general shape of the body, are of higher ordinal value than the presence or absence of anal armature.

The third tribe, Lepturoidini, is easily separable in the larval stage (Fig. 4) from the other two tribes in the first subfamily by having the submentum broad caudad, that is to say, the

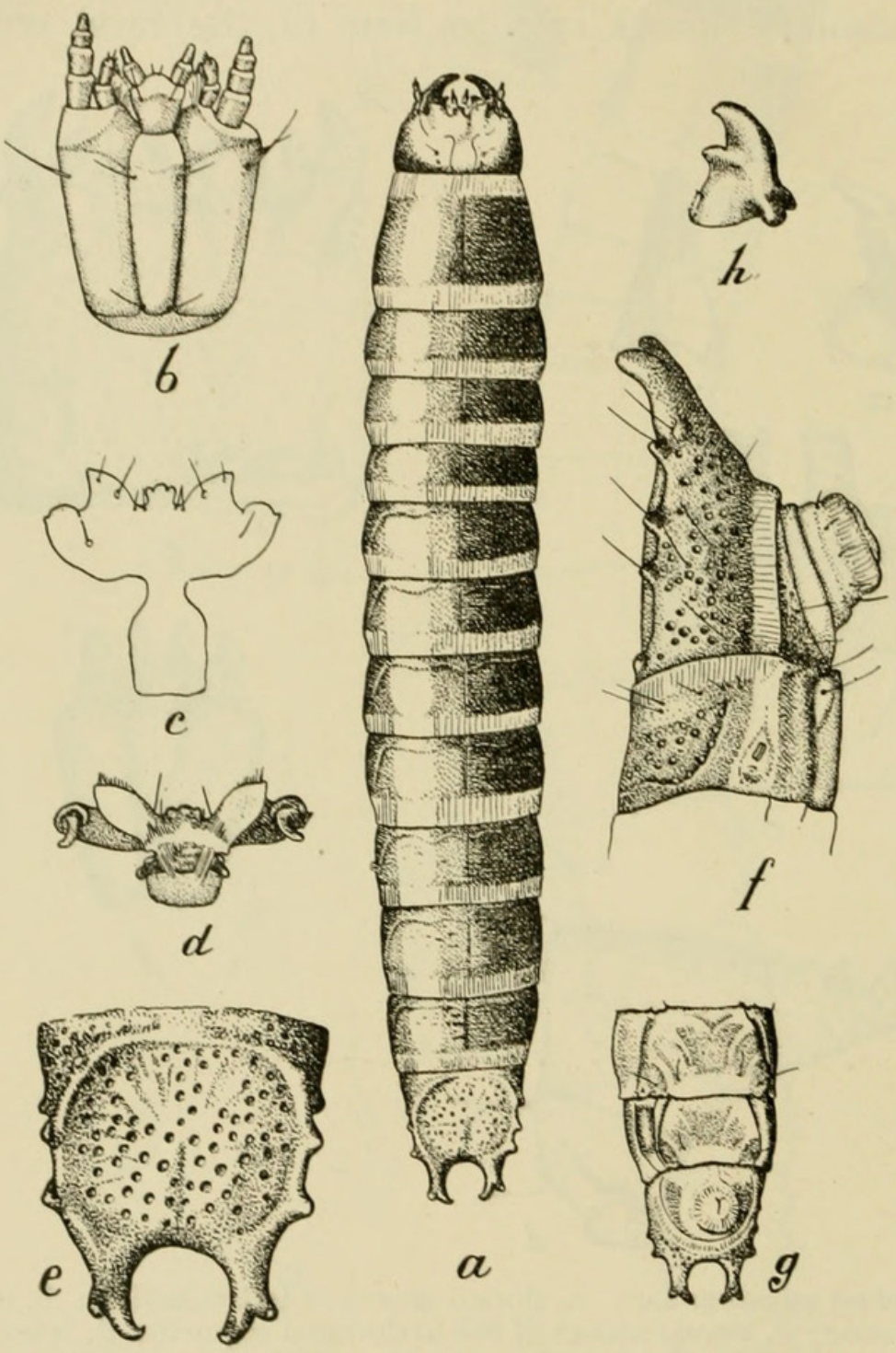

Fig. 4. Athous cucullatus (Say). a, dorsal aspect of larva; b, ventral aspect of labium and maxillae; c, nasale and front; d, anterior aspect of same; $\mathrm{e}$, dorsal aspect of 9 th abdominal segment; f, lateral aspect of 8 th, 9th and 10th abdominal segments; g, ventral aspect of 7 th to 10th abdominal segments; $h$, ventral aspect of left mandible.

stipes-maxillæ widely separated by the posterior part of the submentum; by the absence of armature on the tenth abdominal segment; and by having teeth on the inner surface of the mandibles; while the adults have the cubital cross vein present. 
The tribe Oestodini is tentatively placed in the first subfamily but undoubtedly is much more widely separated from the other three tribes than these are from each other and, as has already been mentioned, is very similar to the so-called Throscid, Drapetes geminatus Say. The larvæ (Fig. 5) are distinguished
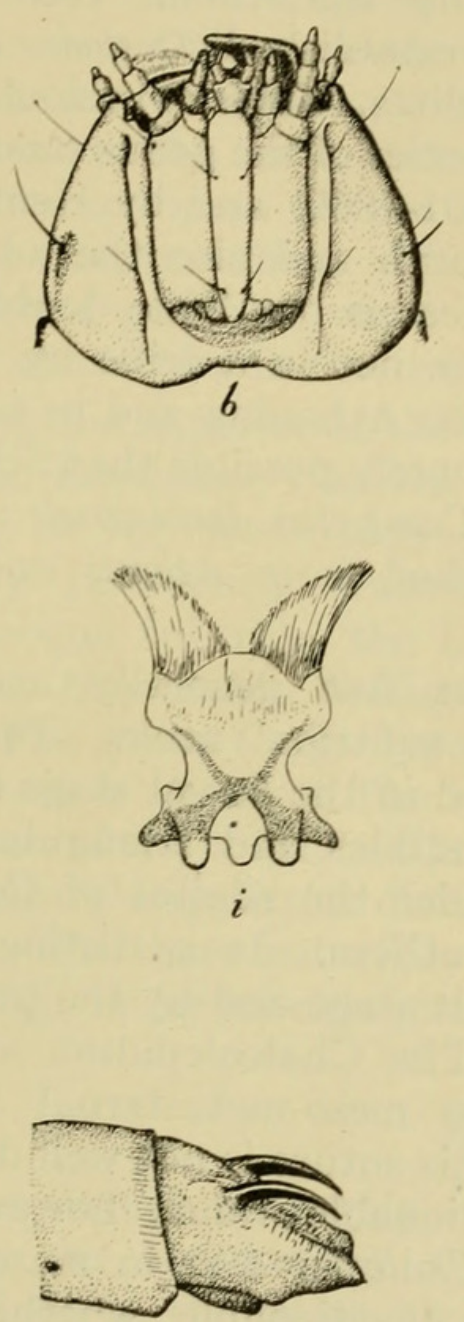

$c$
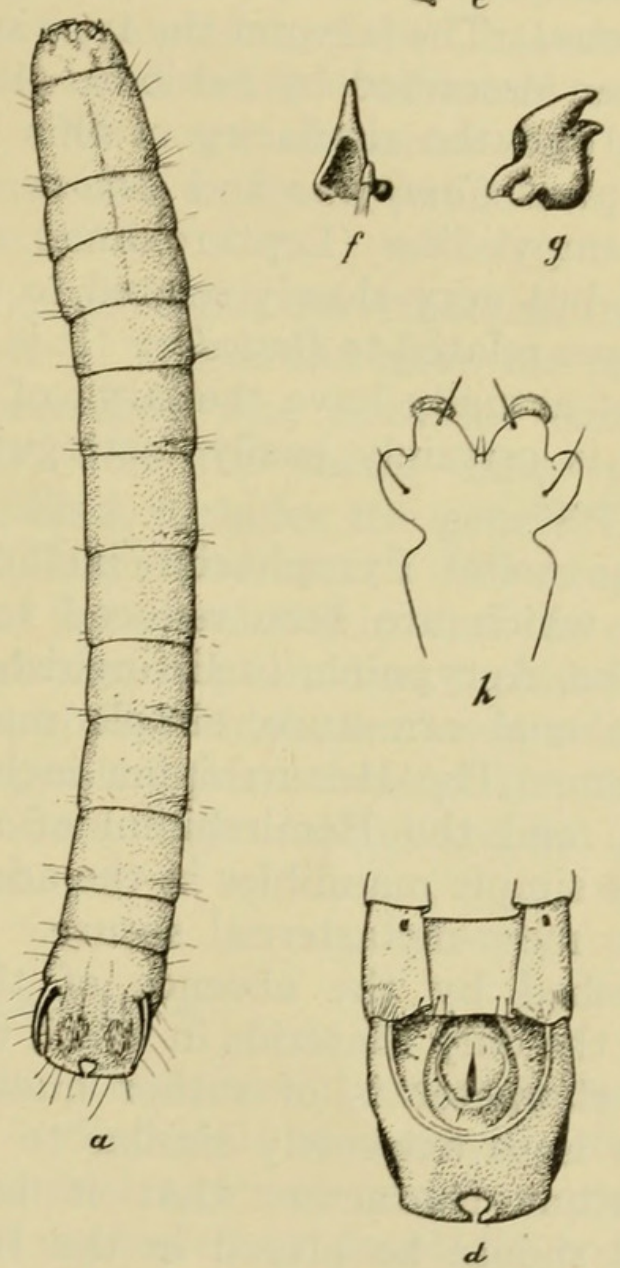

Fig. 5. Oestodes tenuicollis Pand. a, dorsal aspect of larva; b, ventral aspect of head; c, lateral aspect of 8 th, 9th and 10th abdominal segments; d, ventral aspect of same; e, dorsal aspect of right mandible; f, lateral aspect of same; $g$, ventral aspect of same; $h$, front; $i$, hypopharyngial
chitinization.

by the absence of a "nasale," that is to say, the forepart of the fronto-clypeal region is concave instead of being produced into a dentate plate as in all other Elaterid larvæ; the mandibles have a pronounced tooth on the inner edge; and the 
ninth abdominal segment bears two caudally directed stout, curved prongs on its dorso-cephalad surface. The adult is characterized by having the prosternum very short anteriorly, thus leaving the under mouthparts exposed; by having the mesocoxæ contiguous; and the front not carinate, in this last respect being very similar to our subfamily Elaterinæ. Heretofore the insect upon which this tribe is established, Oestodes temuicollis, has been placed in the Campylites. This is undoubtedly erroneous. The larva of the type species of the genus Campylus has been described by Schiodte (1861-1869) and by Henriksen (1911) and the similarity of this larva and also the adult of the typical Campylus and Athous, leaves but little doubt that the Campylidinæ (Lepturoidinæ) are not in a tribe by themselves, but very closely related to the Athouina and in no way whatever related to Oestodes. It is barely possible that Schiodte did not actually have the larva of Campylus denticornis as this insect is certainly easily distinguished from Athous on adult characters.

The tribe Pyrophorini includes five generally accepted tribes which are here reduced to subtribal rank. The first subtribe, Agrypnina, is distinguished in the larval stage by the simple anal armature, simple mandibles and triangular submentum. The Hemirrhipina includes the Alaites of Candeze (1891) and the Hemirrhipini of authors. It is distinguished by the simple mandibles in the adult stage and by the presence of the meso-metasternal suture. The Chalcolepidina are distinguished by the absence of the meso-metasternal suture, being the only Elaterids in which this suture is not well defined. This character is of rather questionable value, however, as Alaus is so extremely similar to Chalcolepidius in many very important characters that it is questionable whether this genus should be placed in the Hemirrhipina or in the Chalcolepidina. Leconte and Horn placed Alaus and Chalcolepidius in the same tribe, excluding Hemirrhipus. The wing venation of the two genera is almost identical; the cubital cross vein arising at the base of the first fork of the cubitus and the radio median cross vein arising at about the middle of the median cell. The Pyrophorina are distinguished from all other Elaterids by the luminous vesicles of the prothorax. The "nasale" in the larvæ has, on its anterior border, seven blunt teeth 
arranged in two rows, three in the upper and four in the lower row. The mandibles are simple and the armature of the tenth abdominal segment consists of accessory spines in addition to the anal hooks, found in all the tribe Pyrophorini. The subtribe Monocrepidina is characterized in the larval stage by the triangular submentum; tridentate "nasale;" simple mandibles; decidedly reduced anal armature. This last character showing a transition from the highly complex armature of the tenth abdominal segment of the Chalcolepidina and Hemirrhipina to the unarmed tenth abdominal segment of the Lepturoidini. The adults are characterized by the broadened posterior coxæ, and convex front, which are exceptional characters in this tribe.

The first subtribe of the Lepturoidini, the Athouina, includes Athous, Limonius, Pheletes, etc. The adults have the anterior carina of the front well developed, the posterior coxæ but slightly broadened inwardly, and the tarsal claws simple. The second subtribe, the Ludiina, includes the genera Cryptohypnus, Hypnoidus, Ludius (Corymbites auct.) Hemicrepidius, etc. The genus Cryptohypnus is exceptional in that the cubital cross vein is absent. The subtribe Lepturoidina includes those members of the old tribe Campylidini which are closely related to the genus Campylus as distinguished from those of the Oestodes tribe. The three subtribes of the Lepturoidini are not as yet separable on larval characters.

\section{ELATERINÆ.}

The second subfamily, the Elaterinæ, is characterized by having the larvæ (Fig. 6) cylindrical or subcylindrical in general form, the ninth abdominal segment never emarginate, and the pleural areas always concealed or decidedly reduced; the adults have the front usually convex, the "plaque nasale" narrow when present, and the antennal fossæ large. This subfamily is divided into five tribes: the first, the Steatoderini, includes Sericosomus, Trichophorus, Orthostethus, etc. The larvæ (Fig. 6) have the ninth abdominal segment smoothly ellipsoidal and the tenth abdominal segment extremely small. 

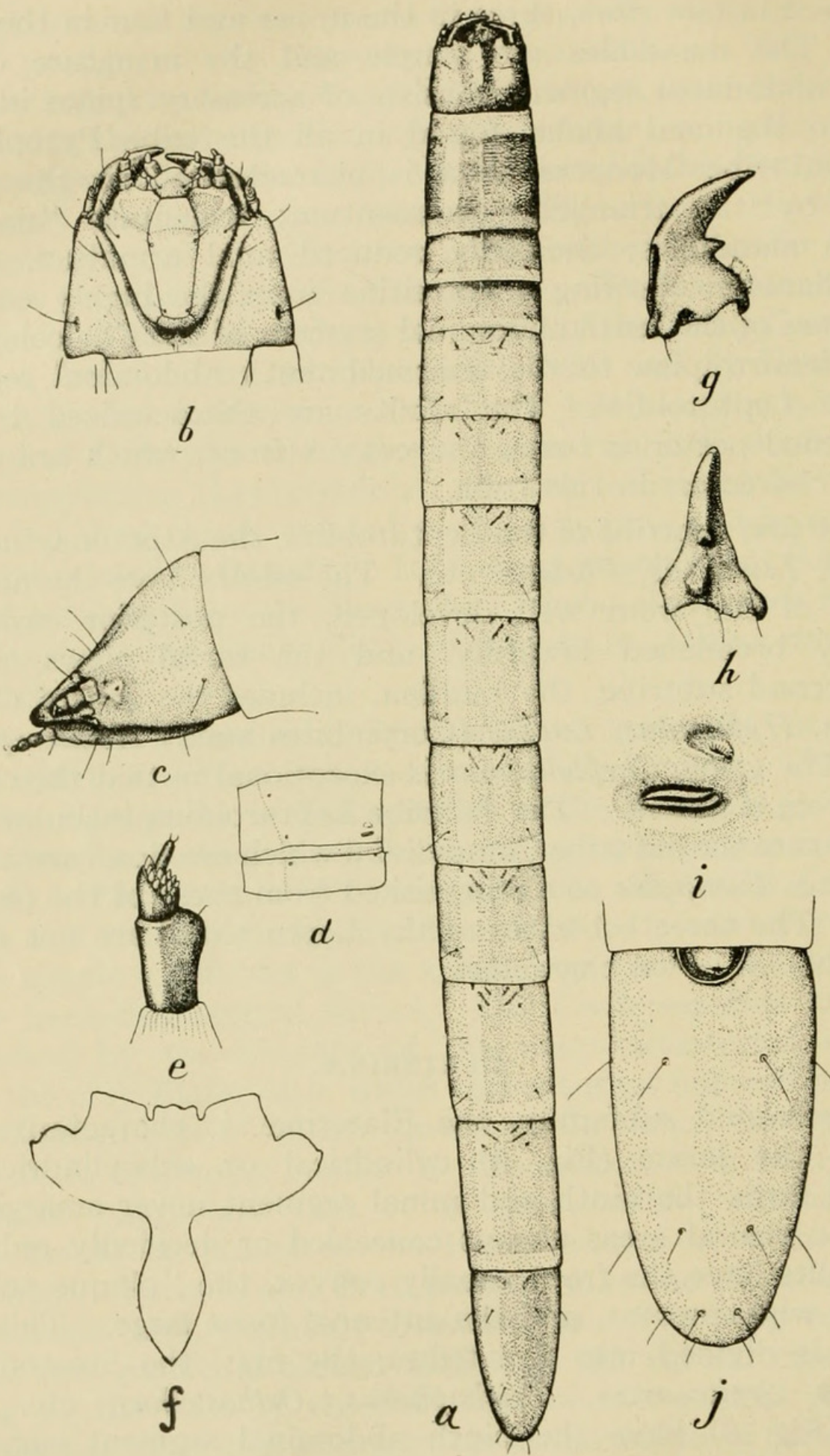

Fig. 6. Orthostethus infuscatus Germ. a, dorsal aspect of larva; b, ventral aspect of head; c, lateral aspect of head; d, lateral aspect of abdominal segment; e, antenna; $\mathrm{f}$, nasale and front; $\mathrm{g}$, ventral aspect of right mandible; h, inner aspect of same; i, abdominal spiracle; $j$, ventral aspect of 9 th and 10th abdominal segments. 
The second tribe, the Agriotini, includes Agriotes, Dolopius, Ectinus, Adrastus, Betarmon, etc. The larvæ (Fig. 7) are characterized by having the "plaque nasale" tridentate; the ninth abdominal segment more or less bluntly pointed caudad,
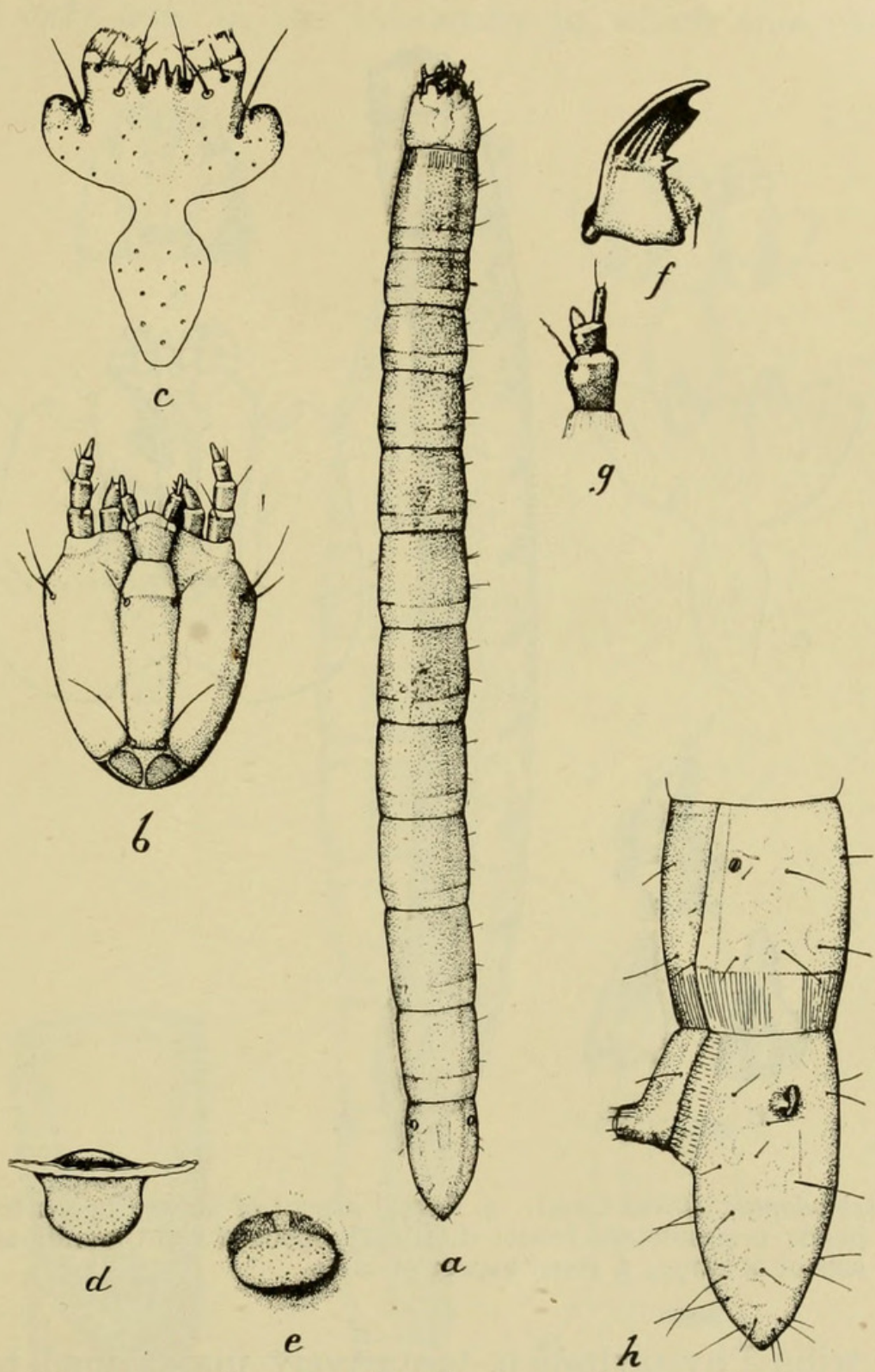

Fig. 7. Agriotes mancus Say. a, dorsal aspect of larva; b, ventral aspect of maxillae and labium; c, nasale and front; d, lateral aspect of invagination on 9 th abdominal segment (dissected out); e, same from inside surface of integument; $f$, ventral aspect of right mandible; $g$, antenna; h, lateral aspect of 8 th, 9th and 10th abdominal segments.

never smoothly rounded as in the Steatoderini, nor bearing a conspicuous terminal spine as in the Elaterini. The adults have the front strongly convex and lack the transverse carina, the mouthparts being directed downward. 
The tribe Elaterini is characterized by the larvæ (Fig. 8) having the "nasale" unidentate; the ninth abdominal segment ending in a conspicuous spine; the transverse muscular impressions on the abdominal tergites very conspicuous.
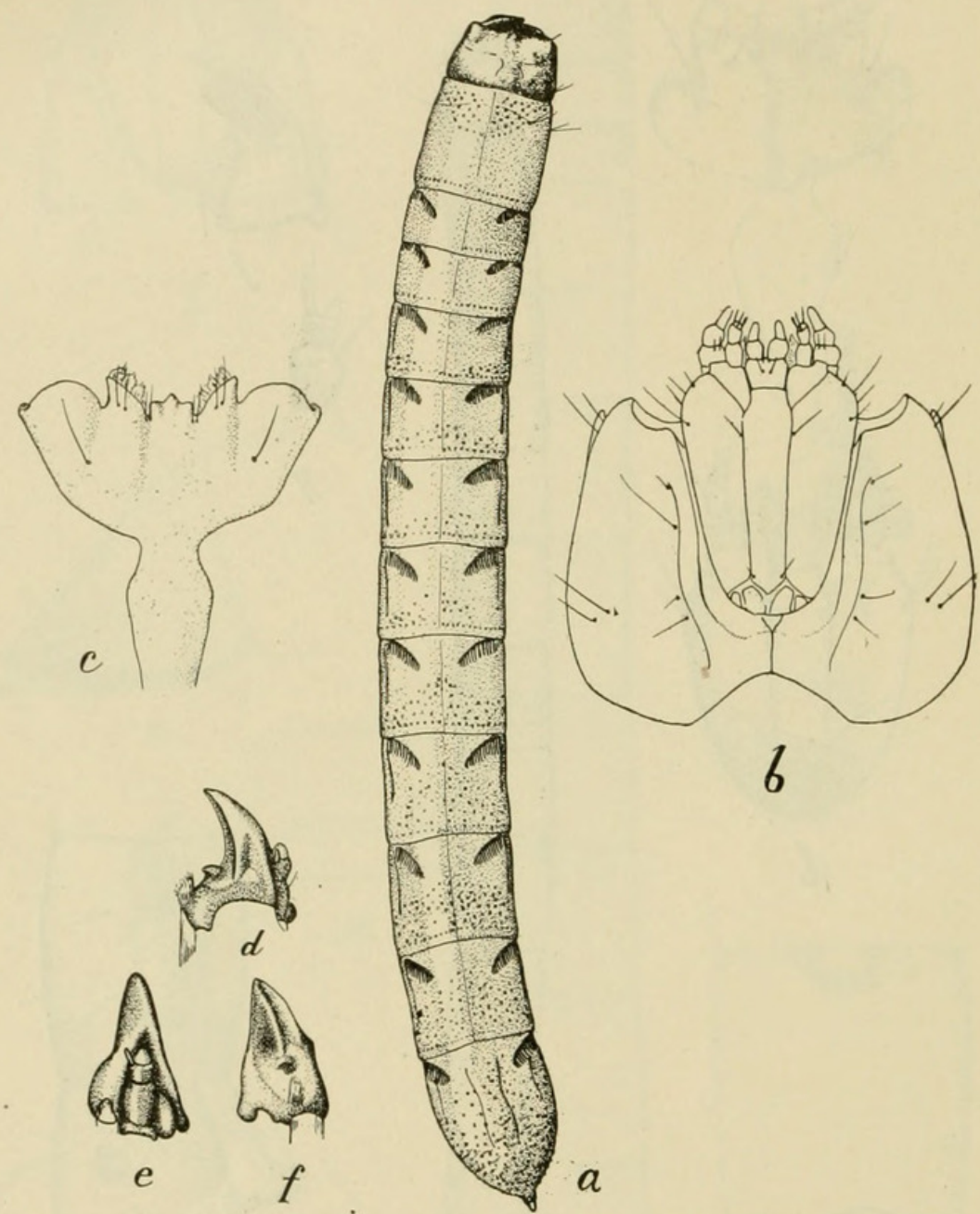

Fig. 8. Ischiodontus oblitus Cand. a, dorsal aspect of larva; b, ventral aspect of head; c, nasale and front; d, dorsal aspect of right mandible; e, lateral aspect of same; $f$, inner aspect of same.

The tribe Physorrhini is tentatively maintained to receive Anchastus. This tribe has been recognized by the leading authorities in this group and I have not had opportunity of examining positively determined larvæ. A larva tentatively determined as Anchastus bears strong resemblance to the larva of Dolopius. 
The tribe Melanotini is characterized in the larval stage (Fig. 9) by having the ninth abdominal segment dorsoventrally compressed caudad and ending in three lobes. The adults are easily recognized by the pectinate tarsal claws, being the only tribe in the subfamily in which this character is present.
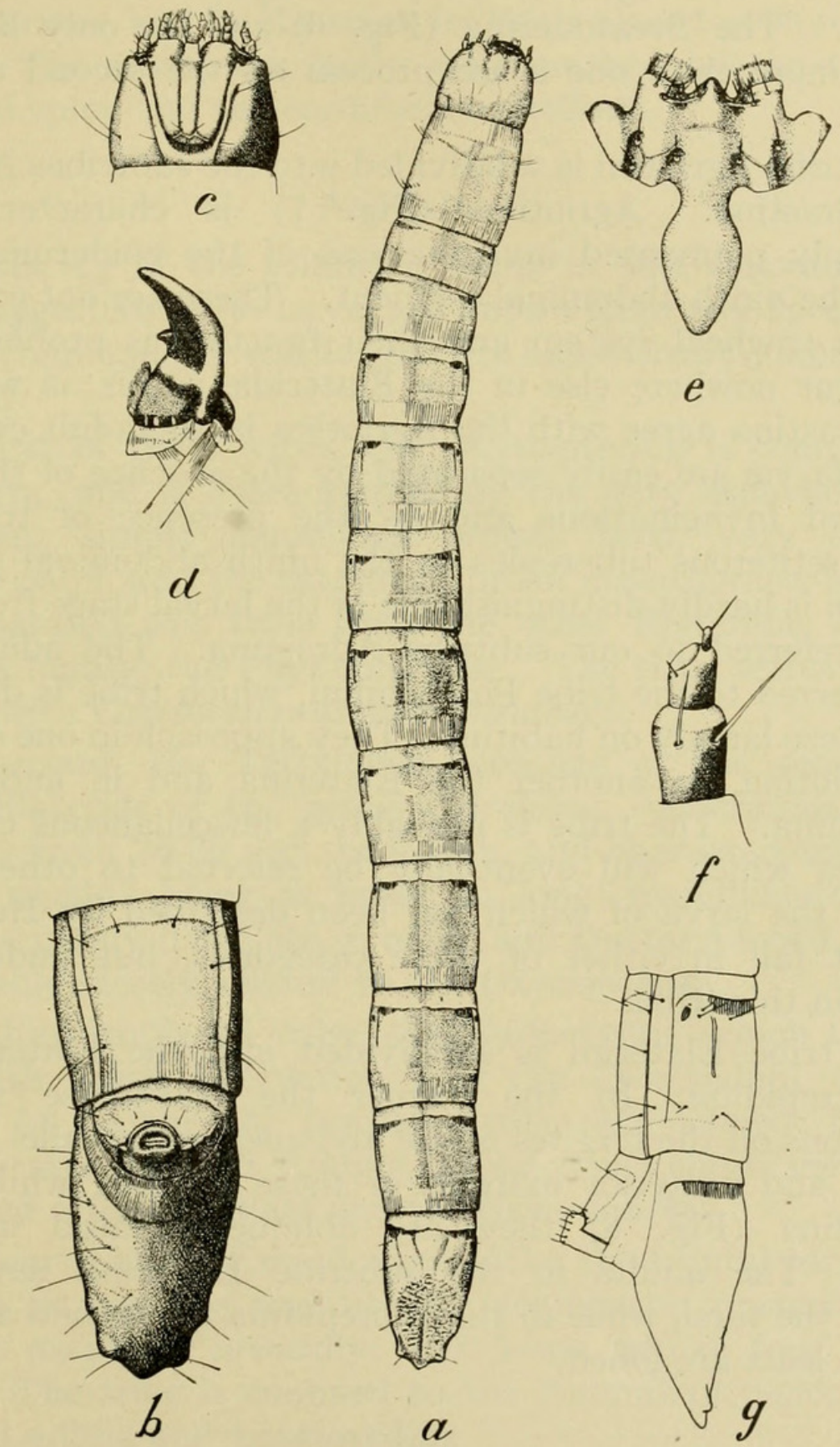

Fig. 9. Melanotus sp. a, dorsal aspect of larva; b, ventral aspect of 8th, 9th and 10th abdominal segments; c, ventral aspect of head; d, ventral aspect of left mandible; e, nasale and front; f, antenna; g, lateral aspect of 8th, 9th and 10th abdominal segments. 
The tribe Steatoderini is subdivided into the two subtribes, Sericosomina to include the genus Sericosomus, and Steatoderina to include Trichophorus, Orthostethus, etc. The strongly convex head of the larva of Sericosomus and the broad penta-tuberculate mandibles with the single sense process (Böving 1910) on the second antennal segment easily distinguish members of this subtribe. The Steatoderina (Fig. 6) are the only Elateridæ bearing more than one sense process on the second antennal segment.

The tribe Agriotini is subdivided into the subtribes Agriotina and Adrastina. Agriotina (Fig. 7) is characterized by two deeply pigmented invaginations of the epidermis on the base of the ninth abdominal segment. These are not connected with the tracheal system and their function is problematical; they occur nowhere else in the Elateridæ as far as we know. The Adrastina agree with the Agriotina in the adult condition, but the larvæ are easily separated by the absence of the above mentioned invaginations and by the presence of transverse rows of setiferous tubercules on the ninth abdominal segment. Betarmon is hardly distinguishable in the larval stage from those species referred to our subtribe Adrastina. The adults have been referred to the tribe Pomachilini, which tribe is diagnosed by Candeze largely on habitus. They approach in one direction the Agriotina, in another the Elaterina and in another the Physorrhina. The tribe is probably a miscellaneous collection of genera which will eventually be referred to other tribes. Ectinus, the larva of which has been described by Henriksen, does not fall in either of these categories, but undoubtedly belongs in this tribe.

The tribe Elaterini is subdivided into the Elaterina and the Dicrepidina. In the former the transverse muscular impressions on the tergites of the abdomen are parallel with the anterior and posterior margins of these tergites, while in the Dicrepidina (Fig. 8) they are obliquely placed upon the tergites. The adults in the subtribe Elaterina never bear lobes on the tarsi, while in the Dicrepidina the second and third joints at least are lobed. 


\section{CARDIOPHORINÆ.}

The subfamily Cardiophorinæ includes the single tribe Cardiophorini and is characterized in the larval condition* by the membranous integument of the body, by the accessory digitate anal lobes, by the mandibles bearing teeth upon the exterior surface, and by the spiracles being placed upon retractile papillæ. The adults are easily distinguished by the truncate prosternal spine and the cordiform scutellum.

\section{AdDENDA.}

The placing of the following tribes in this classification is merely suggestive as no larvæ are known from any species contained therein and my conclusions are based entirely upon adult characters.

The first of these tribes, the Oxynopterini, is composed of four genera, and is characterized by the very excavate front, protuberant simple mandibles, simple tarsi, very elongate maxillary palpi, and the extremely broad metathoracic epimera. Hope separated this tribe from the other Elateridæ, erecting therefor a family, the Phyllophoridæ. The tribe seems to bear affinities with Campsosternus and Tetralobus.

The second, the Tetralobini, consists of the remarkable African Elaterids of the genus Tetralobus. Enormous insects measuring from $30-80 \mathrm{~mm}$. in length, and characterized by the "plaque nasale" being as broad as long; mandibles dentate; antennæ strongly flabellate in male; and the tarsi lobed. They are probably closely related to the Oxynopterini.

The third unplaced tribe, the Eudactylini, which Candeze places with much reservation near the Dicrepidiini, is characterized by having the frontal carina well defined; the prosternal sutures fine and straight; tarsal joints short, very much dilated and often lamellate and the claws simple.

The fourth tribe, Crepidomini, lacks the frontal carina, the front flat or concave and usually acuminate; posterior coxæ gradually narrowed inwardly; and joints two to four of tarsi dilated. The tribe is confined to the Australian region and is allied to Ludiina and Lepturoidina.

* Figured in Bureau of Ent. Bull. n. s. 156, p. 8, Fig. 3b, 1915, and in greater detail in Proc. Ent. Soc. Wash. XVII, p. 179-185, P1. 20, 21, 1915. 
The fifth tribe, the Allotriini, lacks the frontal carina; the front more or less concave; and tarsal joints three and four lamellate at least on anterior tarsi. This tribe is closely allied to the next.

The sixth tribe, the Dimitini, also lacks frontal carina; front slightly declivious and flat; posterior coxæ incomplete exteriorly, that is to say, obliterated at the point nearest the metathoracic epimera. This is a very small tribe in which is placed the anomalous genus Anthracopteryx of Horn.

The seventh tribe, Hypodesini, is erected for the single genus Hypodesis of Central America and Mexico and distinguished by the convex front; large antennal fossæ; frontal carina obliterated above the point of insertion of labrum; super-antennal ridges oblique and short; mouth inferior; tarsal joints two, three and four lamellate; and tarsal claws simple. Intermediate between the Dimitini and the Cardiorhini.

The eighth, the Cardiorhini, is a very natural tribe and easily defined by the large bilobed labrum, which character alone suffices to distinguish these insects which are inhabitants of Tropical America. All the species belong to the genus Cardiorhinus. This tribe, with the three preceding, cannot even be placed hypothetically until the larvæ have been discovered.

The ninth, the Physodactylini, is a tribe erected by $\mathrm{O}$. Schwarz in Genera Insectorum (1906) to receive five small genera from Africa and South America, all of which, with the exception of the type genus Physodactylus formerly referred to the Cebrionidæ, are quite recent.

That many discrepancies will be found in this arrangement of the Elateridæ is inevitable, for though I have examined larvæ of most of the holarctic genera, only a sparse representation of the world's Elaterida are known. The holarctic fauna is extremely weak in Elaterid representatives as compared with the more tropical regions. The great centers of Elateridæ at the present time seem to be the Indo Malayan region and Tropical America. Larvæ of but one or two genera from these regions are known. About six thousand species of Elateridæ have been described for which five hundred and forty-eight genera have been erected. Therefore, we have seen representatives of less than one-tenth of the known genera in the family. 
That this classification is on a much firmer basis than one depending entirely upon adult morphology, needs no confirmation. Many taxonomists have questioned the advisability of attempting to apply to the insects the axiom of the general zoologist, that ontogeny bears out phylogeny, that is to say, that the history of the race is borne out by recapitulation in the history of the individual. They contend that, though undoubtedly the evolution of the race leaves its impressions upon the successive stages in the ontogeny of the extant representative of that race, the insect larva is so actively associated with its environment that adaptive variations will entirely obliterate these phyletic inheritances. Though this is undoubtedly true in a certain degree, and must be considered when reviewing larval characters, it has been overstated, at least in the Elateridæ. Representatives of nearly all the tribes are found in a variety of habitats much more diverse than the habitats of many families of mammals, yet they retain the phyletic characters so as to leave no doubt whatever as to their relationship. For example, larvæ of the genus Melanotus are found in rotten logs, in cultivated fields, under stones, in forest moss, and in mud. No one would question the relationship of the various species of Melanotus, and their larvæ, even under these extremely different habitats, are almost inseparable. Larvæ of the genus Elater are found in rotten logs, in the stems of mushrooms, under stones, and under lichens on exposed boulders, yet an Elater larva can be recognized at a glance, and no important phyletic characters have been obscured by adaptive modifications. I believe it more logical to accept ontogenic evidence, with reasonable reservation, than to blindly follow adult comparative morphology, without taking into consideration the enormous possibility of error on account of convergent variation due to the fact that the adult Elaterids are much less diverse in habits than are their larvæ. As far as we know their habits, they all frequent flowers and leaves and are exclusively phytophagous, while the larvæ live in practically all habitats, except the truly aquatic, and are both carnivorous and phytophagous.

The Schematic tree (Fig. 10) is arranged to express my concept of the phylogeny of the Elateridæ, of which the larvæ are now known. The vertical elevation of the origin of the 
various branches is but very roughly indicative of a relative time displacement. The lateral arrangement of the genera is intended to indicate the superficial relationship of the present day genera. The sub-families Pyrophorinæ and Elaterinæ evidently branched off in the quite remote past.

The paleontological record has recently been carefully studied by Professor Wickham,* who has presented a most excellent review of our knowledge of the fossils of these insects.

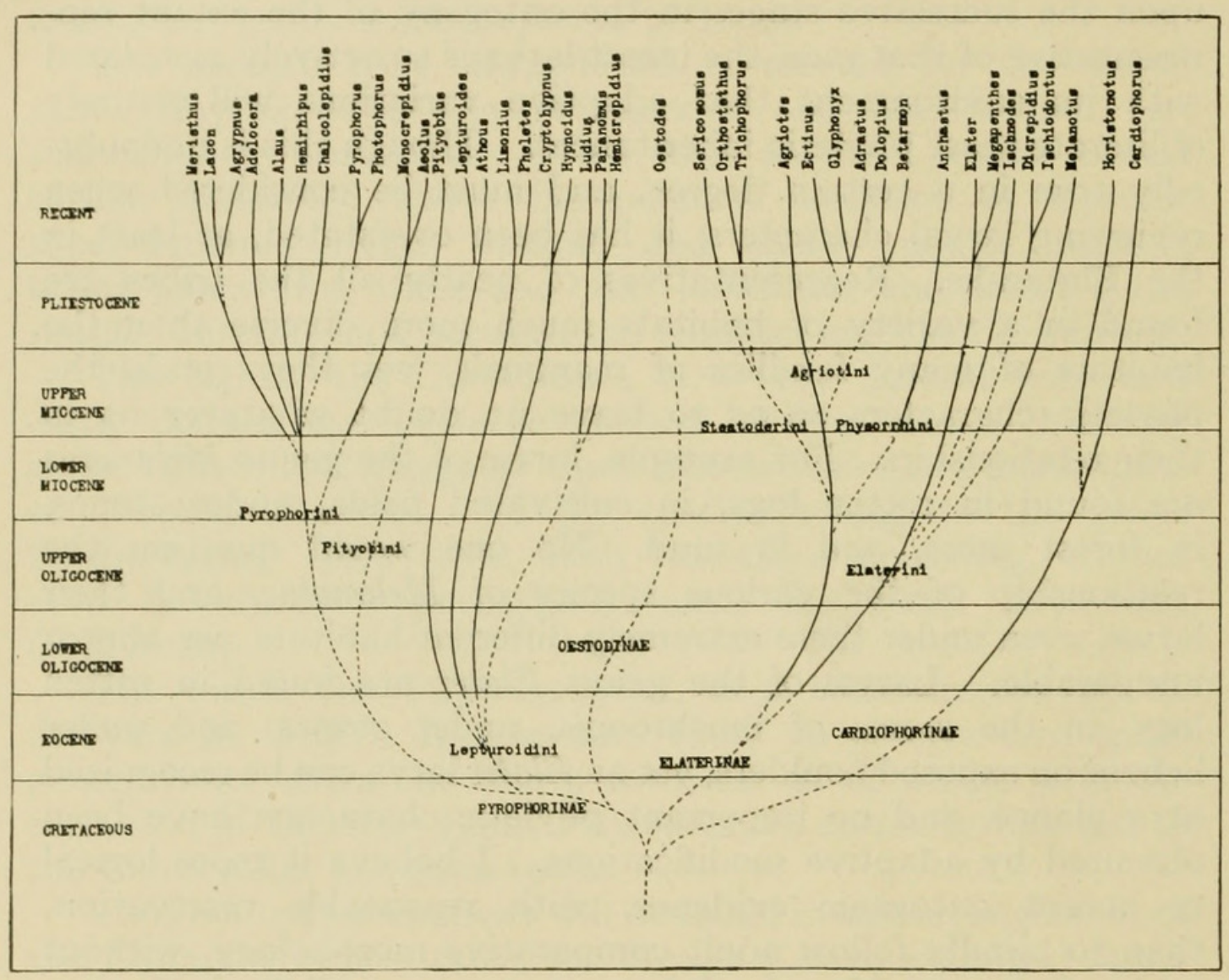

Fig. 10. Schematic Phyletic Arrangement of the Elateridae. Solid lines indicate known geologic time that genera were extent. Dotted lines are hypothetical.

Fossils having a decided Elaterid habitus are found at the base of the Mesozoic era in the Triassic rocks, these specimens, recorded by Handlirsch, bear no character, however, which can definitely place them in this family. Similar fossils are also found in the Liassic. The Jurassic chalks bear fossil insects which are decidedly elateriform, but the placing of

* Bull. Mus. Comp. Zool. LX, No. 12, p. 493-527, 1916. 
such in our present genus Elater is hardly justified. It is probably safe to place the original Elaterid stem in the upper Jurassic. The palontological record is blank from the time of these earlier fossils until the early Tertiary. The baltic ambers of the Lower Oligocene contain Elateridæ so well differentiated as to be referable to extant genera. Eucnemidæ are very numerous, as would naturally be expected in Amber faunas. The Cardiophorinæ had already split off from the parent stock, probably in the Upper Cretaceous. The Pyrophorinæ were already differentiated into their main tribes, but what seems most remarkable is that the Lepturoidini and not the more conspicuous Pyrophorini are represented. In fact, the Pyrophorini are not recorded until the Upper Miocene where they abound in both the Oeningen beds in Europe and in our own Florissant of Colorado. This seems to indicate that our tribe Pyrophorini left the Pyrophorinæ stem at a much later period than the tribe Lepturoidini. The great gap in the record covers the period in which the greatest Elaterid diversification took place, that is in the Cretaceous and lower Eocene.

\section{Family ELATERIDAE.}

Italicized tribes and sub-tribes are tentatively placed, as larvae of species have never been described.

Subfamily Pyrophorinae

1. Tribe Pyrophorini

Sub tribe Agrypnina

Sub tribe Hemirhipina

Sub tribe Chalcolepidina

Sub tribe Pyrophorina

Sub tribe Monocrepidina

Tribe Oxynopterini

Tribe Tetralobini

2. Tribe Pityobini

Sub tribe Pityobina

3. Tribe Lepturoidini

Sub tribe Athouina

Sub tribe Lepturoidina

Sub tribe Ludiina

Tribe Crepidomini

4. Tribe Oestodini

Sub tribe Oestodina

Tribes not yet located:

Tribe Allotriini

Tribe Dimitini
Subfamily Elaterinae

1. Tribe Steatoderini

Sub tribe Sericosonina

Sub tribe Steatoderina

2. Tribe Agriotini

Sub tribe Agriotina

Sub tribe Adrastina

3. Tribe Elaterini

Sub tribe Elaterina Sub tribe Dicrepidina

Tribe Eudactylini

4. Tribe Physorrhini Sub tribe Physorrhina

5. Tribe Melanotini Sub tribe Melanotina

Subfamily Cardiopherinae Tribe Cardiophorini Sub tribe Cardiopherina

Subfamily Physodactylinae

Tribe Hypodesini Tribe Cardiorhini 


\section{$2 \mathrm{BHL}$ Biodiversity Heritage Library}

Hyslop, James Augustus. 1917. "The phylogeny of the Elateridae based on larval characters." Annals of the Entomological Society of America 10, 241-263.

View This Item Online: https://www.biodiversitylibrary.org/item/43648

Permalink: https://www.biodiversitylibrary.org/partpdf/39534

\section{Holding Institution}

Smithsonian Libraries

\section{Sponsored by}

Smithsonian

\section{Copyright \& Reuse}

Copyright Status: NOT_IN_COPYRIGHT

This document was created from content at the Biodiversity Heritage Library, the world's largest open access digital library for biodiversity literature and archives. Visit BHL at https://www.biodiversitylibrary.org. 